\title{
INNOVATION VOUCHERS AS A MODERN FINANCIAL TOOL FOR THE DEVELOPMENT OF SMES
}

\author{
Alla Ivashchenko', Anna Kornyliuk' ${ }^{2}$, Yevheniia Polishchuk ${ }^{3}$
}

\begin{abstract}
The subject of the study is innovation vouchers as a modern tool to support "green" SME projects. Innovation vouchers are financial instruments that perform a number of functions for the development of SMEs. They can stimulate its cooperation between research institutes or universities in the development of innovations and implementation of innovative solutions. It can become an alternative more effective tool for the use of public funds. Innovation vouchers formed the basis of financial support for the implementation of the development strategy of the region in the context of smart specialization. In the countries of the Eastern Partnership, such tools are only part of the practice, while the OECD countries have been actively using them for more than 10 years. In this regard, it was decided to analyze existing SME support programs using innovation vouchers in OECD countries and to give practical recommendations for the implementation of foreign experience in the development of SME support policies in the Eastern Partnership countries. The main method of research is the analytical method. A critical analysis of the scientific literature and policy documents helped form the concept of the use of innovation vouchers by SMEs. The study analyzed 47 programs to support SMEs with innovation vouchers, which operated for 12 years (from 2008 to 2020). Both quantitative indicators (total value of the program with innovation vouchers, maximum voucher value, etc.) and qualitative data (target group, directions of innovation financing) were taken into account. Classification features of innovation vouchers, their target audience, distribution of programs among target group participants (SMEs, companies of different ages, universities, state research institutes, microbusinesses, incubators, gas pedals, science parks, etc.), cost of vouchers, validity of innovation vouchers were determined. The main conclusion may be that when introducing innovation vouchers as tools to support micro-, small- and medium-sized businesses, it must be taken into account that the circle of knowledge providers must be broad (it may include private and public research organizations, universities, and other relevant types of providers). The requirement for co-financing needs to be met as well in order to reduce the risks of inefficient use of funds. In addition, support for innovative enterprises should be broadcast at all levels: local and national. The following target stakeholder groups can benefit from the results of the study: research institutes, universities, SMEs, policy makers, government, NGOs involved in innovation support, etc.
\end{abstract}

Key words: financial instruments, SMEs, innovation vouchers, R\&D.

JEL Classification: G10, G20, O31, O32

\section{Introduction}

SMEs are the driving force of economic growth. In Ukraine it reaches more than $95 \%$ of operating enterprises. In addition to the fact that SMEs are the main employer in different countries around the world, in order for it to skillfully perform the function of a driver, it is necessary to create conditions for the development and implementation of innovation in its activities. Innovative SME development and management strategies often run counter to survival and result in survival, or managers choose inefficient development paths. Moreover, development requires innovative solutions; on the other hand, it is difficult for entrepreneurs to allocate funds for the development of

\footnotetext{
Corresponding author:

${ }^{1}$ State Higher Educational Institution Kyiv National Economic University named after Vadym Hetman, Ukraine.

E-mail: alla.ivashchenko@kneu.edu.ua

ORCID: https://orcid.org/0000-0002-4599-7137

${ }^{2}$ State Higher Educational Institution Kyiv National Economic University named after Vadym Hetman, Ukraine.

E-mail: anna.kornyliuk@kneu.edu.ua

ORCID: https: //orcid.org/0000-0001-8713-0681

${ }^{3}$ State Higher Educational Institution Kyiv National Economic University named after Vadym Hetman, Ukraine.

E-mail: polishchuk@kneu.edu.ua

ORCID: https://orcid.org/0000-0002-6133-910X

ResearcherID: J-5444-2018
} 
innovation. Another problem is the lack of personnel who could deal with these developments. This gave rise to the idea of creating such a financial instrument as an innovation voucher. On the one hand, it combines the goals of SMEs and research institutes or universities capable of conducting research and development, and on the other hand, such instruments make it possible to successfully manage the inefficient use of public funds through the mechanisms of innovation vouchers.

Although innovation vouchers are not a new phenomenon in the economy, there is a lack of generalizations in the classification of innovation vouchers, foreign experience and its use in Ukraine or other EaP countries, as well as the concept of using innovation vouchers by SMEs.

Therefore, the main purpose of this article is to examine successful examples of the use of innovation vouchers for SMEs in different countries and to offer recommendations for policymakers and other stakeholders on their application in emerging economies.

The objectives of the study are as follows:

- to analyze SME programs in the EU and other countries where innovation vouchers are used as a financial tool for innovation development;

- to develop a classification of target groups of innovation vouchers and determine the type of knowledge provider;

- to analyze Requirements for co-financing projects in different cases;

- to develop a Concept for the use of innovation vouchers by SMEs.

Methods and data research. This article discusses the key features of innovation vouchers as an important mechanism of financing innovative development of SMEs. The analytical method is used to determine the design of innovative voucher programs. As a result, a conceptual scheme of innovation voucher based on 5 key characteristics of the instrument was formed. For this purpose, the database of innovation voucher policy instruments was studied. The total sample includes 57 innovation voucher programs over the past 12 years (2008-2020). Both quantitative data (total program funding, maximum voucher amount) and qualitative data (target groups, thematic areas) were used for the study.

Literature review. As the sustainable development goals have become the number one issue on the global agenda, green financial instruments are seen as the main key to solving "green" problems. Therefore, researchers in the financial field have looked at innovative vouchers from different perspectives.

Various types of innovation voucher mechanisms have been described in the relevant literature: innovation vouchers with subsidized costs for business or technical services from external suppliers (Langhorn, 2014). The literature emphasizes the importance of innovation vouchers as tools for building regional development capacity. For example, in the Czech Republic in the Ústí, innovation vouchers supported SMEs in cooperation with research centers - consumption from activities increased by $26 \%$ and the book value added increased by $25 \%$. At the same time, there was a $9 \%$ increase in personnel costs between 2013 and 2015. Another region of the Czech Republic, Ostrava, also shows successful support for technology transfer in the field of biotechnology through innovation vouchers (Matulova, Stemberkova, Zdralek, Maresova, \& Kuca). Green financial instruments in the Western Balkans are seen as essential for achieving sustainable development goals (Luksic, Boskovic, Novikova, \& Vrbensky, 2021; Doranova, Griniece, Miedzinski and Reid; Shevchenko et al, 2021; Kholiavko et al, 2021). In Italy, innovation voucher programs have a regional context. For example, the region of Lombardy has a strong experience in launching such programs. Sala, Landoni and Vergomnti (2015) highlighted the advantages of these instruments and their impact on the innovative development of SMEs and their collaboration with local research centers and universities.

In China, innovation is quite a popular tool for green projects. Zhao and Radziwon (2021) emphasized the effectiveness of such tools for SME development in the context of demand-side policies to promote sustainability and resilience. Green finance and innovation vouchers, in particular, can help Chinese companies become resilient to the challenges posed by COVID-19 (Sadiq et al., 2021).

On the policy-making side, this tool is also considered by Guerrero and Urbano (2019). They have proven that it can be successfully implemented as a policy and has a direct and indirect contribution to the development of cooperation between SMEs and universities.

Other literature focuses on case studies in which innovation vouchers helped turn an idea into a product. Using the example of antibiotic vouchers in the United States, Outterson \& McDonnell (2016) demonstrated the partial effectiveness of this financial instrument because of the length of the exclusivity period, the relationship between value and reward, the encouragement of high-quality innovation, and the retention of vouchers for appropriate cases. Innovative vouchers were also used to prevent malaria in Ghana and Tanzania (Don de Savigni et al., 2012). In other African countries (Nigeria and Brunei), green vouchers and other financial instruments are offered to agricultural enterprises (Raimi, Olowo, \& Shokunbi, 2021). Another example of a targeted application is green mining. It can also be useful for the eastern 
regions of Ukraine, where mining is one of the leading industries (Shavina and Prokofiev, 2020). As a financial instrument, the innovation voucher can be used even in the implementation of social projects (Shein, Payusov, \& Kurdyumov, 2020), turism (Yakymchuk et al., 2021), education (Shkarlet, Kholiavko, Dubyna, 2019), and for the development of green energy industry (Chiu, Lin, Liang, 2021).

Innovation vouchers can be distributed in different ways. For example, in the Netherlands, they are distributed by lottery (Cornet, Vroomen, and Van Der Steeg, 2006).

Schade and Grigore (2009) point out as an advantage of innovative vouchers that they require less bureaucracy than grants. Spiesberger \& Schönbeck J. (2019) hold a similar opinion. The mentioned work is interesting because the authors study the experience of Armenia, Belarus, Georgia and Moldova, which can be useful for Ukraine. A sample group of innovation vouchers was considered, and without any doubt the authors argue that this financial instrument is quite successful in stimulating the use of renewable energy sources and energy efficiency.

\section{Innovation vouchers as key tools for enhancing innovations by SMEs}

Taking into account that in most cases SMEs have limited opportunities to develop and implement innovations and conduct $\mathrm{R} \& \mathrm{D}$ due to the lack of funding, relevant experts and experience in this area, some small-scale financing schemes could be useful for SME development in this direction. According to the Innovation Policy Platform, innovation vouchers are one of the most popular funding mechanisms, which involves issuing state support funding (mainly up to $€ 10,000$ ) to SMEs, which can only be distributed to knowledge providers (universities, R\&D institutes, innovation centers, etc.). This type of support provides many potential benefits for the work of SMEs, such as stimulating innovation, strengthening cooperation between SMEs and R\&D and knowledge providers, enhancing knowledge transfer, and eliminating information asymmetries for SMEs.

Another feature of this support is the possibility for SMEs that do not have their own sources to use the R\&D capabilities of other institutions. Innovation voucher support can be provided at the local, regional and national level by public authorities and can be directed directly to the predetermined goals of the respective Voucher Program. The other side of the usefulness of the innovation voucher scheme is that $R \& D$ and knowledge providers also receive funding to carry out their core business of developing and implementing innovation.
For a better understanding, the main characteristics of innovation vouchers, namely objectives, implementation algorithm, potential benefits and risks for SMEs, as well as the most influential factors are presented in Figure 1.

Among the theoretical concept of innovation voucher schemes that are beneficial to both SMEs and $\mathrm{R} \& \mathrm{D}$ and knowledge providers, applied examples of the use of innovation vouchers are of great importance. Examples of such applications are analyzed in Appendix 1 in various areas such as construction, manufacturing, business services, logistics, etc.

According to the OECD's Innovation Voucher Policy Dashboard, 27 countries, mostly from the EU, Asia, South America, and Australia, implemented innovation vouchers during the years under study. On average, one country implemented two innovation voucher programs, while Portugal, Austria, and Belgium were the leaders in the number of implemented programs with nine, six, and five implemented, respectively.

The number of innovation voucher programs over the study period is shown in the graph. The data show a gradual increase in the use of innovation vouchers since 2008. The maximum popularity was achieved in 2016, after which there is a gradual decline in the popularity of this tool.

A detailed study of existing programs allowed to form a conceptual scheme of innovation vouchers based on 5 main characteristics, in particular: 1) target groups; 2) type of knowledge provider; 3) annual funding range of the program and the maximum amount of funding per innovation voucher; 4) program duration; 5) requirements for co-financing of projects.

\section{Target group}

An important component of innovation voucher programs is the identification of the main recipients, i.e., the groups eligible to receive funding. Table 1 presents the main classification attributes and corresponding target groups based on the database of innovation voucher policy instruments (Table 1).

The analysis showed that there is a wide range of recipients, both private and public. In addition, some initiatives are aimed at targeted support of certain groups of the population. For example, the development of innovation voucher programs in Malta and South Korea involves providing vouchers to certain lowincome groups. Such groups usually include people with disabilities, those who are at high risk of poverty, etc. Such initiatives have not only an economic but also a social impact, contributing to social inclusion. In addition, Malta specifically supports women, thereby motivating them to engage in research and innovation and reducing the gender imbalance. 


\section{INNOVATION VOUCHERS}

Main goal: to strengthen cooperation between SMEs and universities/R\&D institutions in order to implement innovation at company level through knowledge transfer on the basis of funding of up to 10,000 euros.

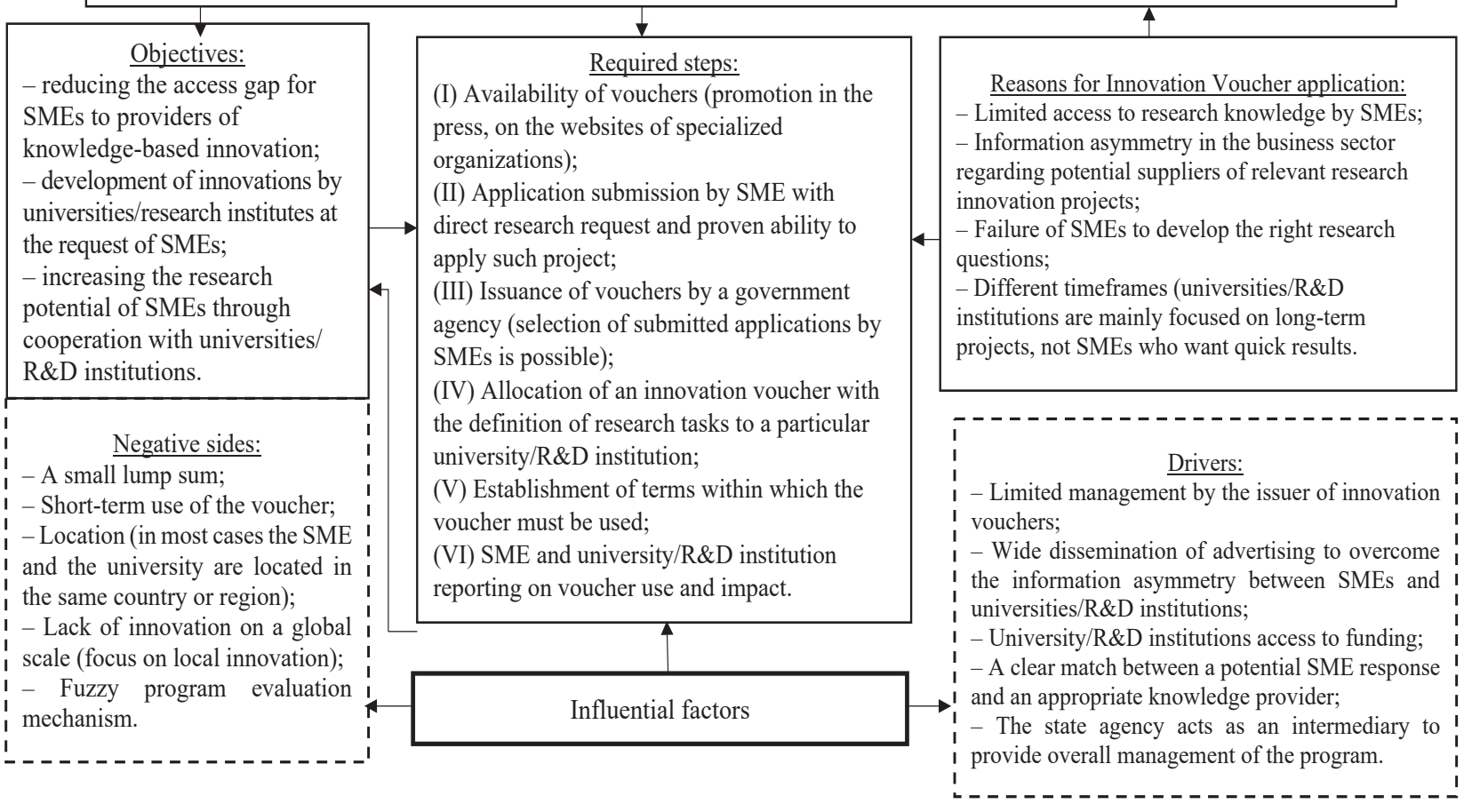

Figure 1. Concept of SME innovation vouchers application

Source: (Cornet, Vroomen Björn, Marc van der Steeg, 2006; Shkarlet, Kholiavko, Dubyna, 2019; Voucher schemes in member States - European Commission)

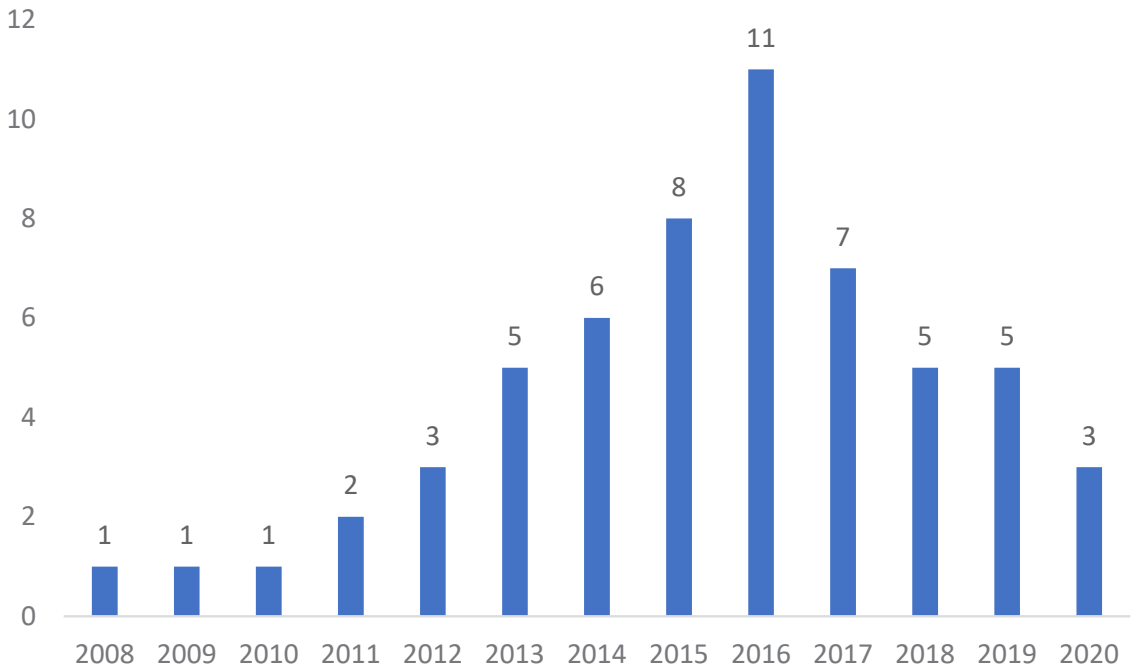

Figure 2. Number of innovation voucher programs in 2008-2020 in OECD countries

Source: Based on OECD Innovation vouchers Policy Instrument Dashboard

The next step of the study was to determine the most common target groups (Table 2).

The data show that the greatest support is directed at SMEs and businesses without an indication of their age.

\section{Type of knowledge provider}

The next step was to analyze the main types of knowledge providers, i.e., organizations that will be suppliers of innovative developments, new technologies, etc. In total, 4 groups of suppliers 
Table 1

Innovation vouchers target groups classification

\begin{tabular}{|l|l|}
\hline \multicolumn{1}{|c|}{ Classification feature } & \multicolumn{1}{c|}{ Target groups } \\
\hline Companies by age & Any age, nascent, young or established companies \\
\hline Companies by size & SMEs, micro-enterprises, companies of any size \\
\hline Research and education institutions & HEI, public or private research institutes \\
\hline Intermediaries & $\begin{array}{l}\text { Incubators, accelerators, science parks or technology parks, Technology transfer offices, Industry } \\
\text { associations }\end{array}$ \\
\hline Economic actors (individuals) & Entrepreneurs \\
\hline Governmental entities & National and Subnational government \\
\hline Researchers, students and teachers & $\begin{array}{l}\text { PhD students, Postdocs, Secondary education students, Teachers, Undergraduate and master } \\
\text { students, Established researchers }\end{array}$ \\
\hline Social groups especially emphasized & Civil society, Disadvantaged and excluded groups, Women \\
\hline
\end{tabular}

Source: Based on OECD Innovation vouchers Policy Instrument Dashboard

Table 2

Innovation vouchers target groups distribution

\begin{tabular}{|l|c|c|}
\hline \multicolumn{1}{|c|}{ Target group } & Number of Programs & Percentage of programs \\
\hline SMEs & 40 & $15,4 \%$ \\
\hline Firms of any age & 36 & $13,8 \%$ \\
\hline Firms of any size & 15 & $5,8 \%$ \\
\hline HEIs & 15 & $5,8 \%$ \\
\hline Public research institutes & 15 & $5,8 \%$ \\
\hline Entrepreneurs & 13 & $5,0 \%$ \\
\hline Micro-enterprises & 12 & $4,6 \%$ \\
\hline Incubators, accelerators, science parks or technology parks & 10 & $3,8 \%$ \\
\hline National government & 10 & $3,8 \%$ \\
\hline Private research institutes & 10 & $3,8 \%$ \\
\hline Established researchers & 8 & $3,1 \%$ \\
\hline Nascent firms & 8 & $3,1 \%$ \\
\hline PhD students & 8 & $3,1 \%$ \\
\hline Technology transfer offices & 8 & $3,1 \%$ \\
\hline Other & 52 & $20,0 \%$ \\
\hline
\end{tabular}

Source: Based on OECD Innovation vouchers Policy Instrument Dashboard

Private business

Mixed

$\mathrm{HEI}$ and Public research institutes

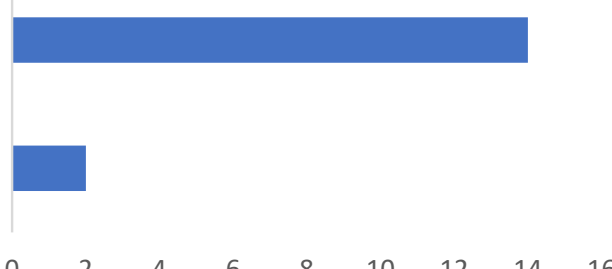

Number of programs

Figure 3. Distribution of programs by type of knowledge provider

Source: Based on OECD Innovation vouchers Policy Instrument Dashboard.

Data available only for 47 programs 
were singled out: private business, universities and state research institutes, mixed and other suppliers. The mixed category includes initiatives that include several types of knowledge providers. It is noteworthy that most programs involve the active participation of private business, including SMEs, in innovative transformations.

\section{The range of annual program funding and the maximum amount of funding per innovation voucher}

The data show that about half of the programs have annual budgets of less than 5 million euros and only two programs have budgets of more than 100 million euros. The Colombian program has a budget of 100-500 million euros, and the program itself runs for 8 years and aims to support R\&D in business. The largest program, more than 500 million euros, was founded by South Korea in 2020 and aims to develop key STI activities.

As for the maximum possible financing, the most popular instruments are those exceeding 10 thousand euros, followed by instruments up to 6 thousand euros.

Only 17 programs have information about the duration of the program. The analysis showed that, on average, the program lasted for 5.5 years. Austria and Italy implemented their programs for two years, and Poland for 11 years.

Participation in some of the innovative voucher programs studied requires additional funding from other sources, that is, the amount of the voucher should not cover the full cost of the project. It is believed that such a situation can serve as a safeguard against the misuse of public funds. Of the initiatives analyzed, 37 (or 57\%) require an additional

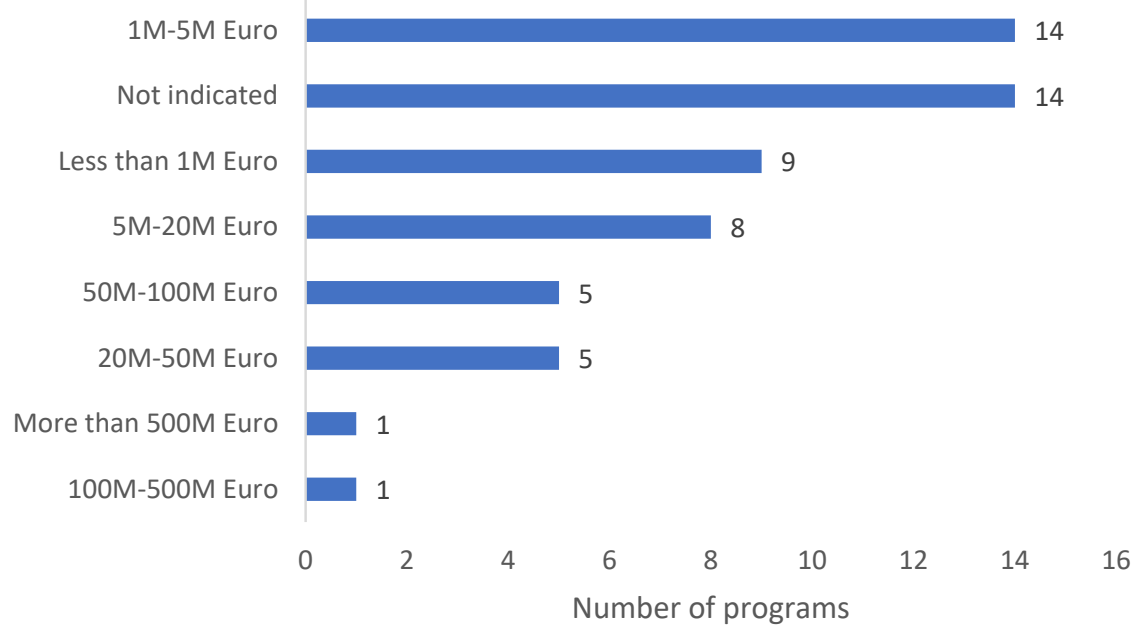

Figure 4. Distribution of programs by amount of funding

Source: Based on OECD Innovation vouchers Policy Instrument Dashboard

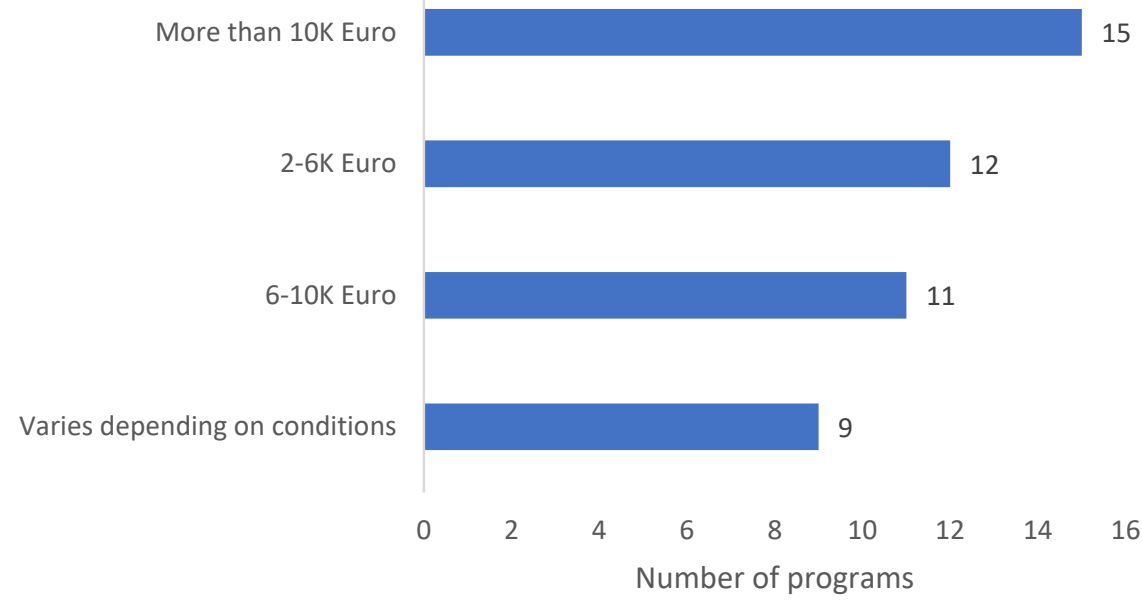

Figure 5. Distribution of programs according to the maximum amount of the innovation voucher

Source: Based on OECD Innovation vouchers Policy Instrument Dashboard. Data available only for 47 programs 
contribution, $14(25 \%)$ require no contribution, and 11 (19\%) require no information. Thus, the vast majority provides for co-financing from other sources.

\section{Conclusions}

The study of individual programs of innovation vouchers allowed to form their key characteristics. In particular, it was found that this instrument is aimed at supporting a wide range of target groups. However, a detailed analysis showed that it is primarily aimed at supporting SMEs and firms without any indication of age or size. In addition, there are programs specifically designed for microbusinesses and individual entrepreneurs. In addition, among possible knowledge providers, preference is often given to private businesses, a large part of which are also SMEs. The amount of an innovation voucher is usually small (up to 10 thousand euros), and in most cases the recipient must provide co-financing. In our opinion, the requirement to invest additional funds reduces the risks of inefficient investment of public funds.

The study will contribute to the formation of an effective design of innovation vouchers for SME development in those countries that are only planning to implement such programs to support innovative development. In particular, understanding the key features and existing options for target groups, key topics, etc. will allow programs to be implemented that will better meet the needs of SMEs.

The following recommendations can be made. Firstly, innovation voucher programs should include a broad list of knowledge providers: private and public research organizations, universities, and other relevant types of providers. This will greatly expand access of SMEs to innovative knowledge and accelerate their development. Secondly, it is necessary to implement the requirement for co-financing. It is also believed that requiring SMEs to invest their own additional funds reduces the risks of inefficient investment of public funds. Thirdly, state agencies should implement a specific framework for issuing innovation vouchers with predetermined conditions and criteria for their allocation and timing for their use. Finally, the encouragement and promotion of innovation voucher support policies should be carried out at all levels, namely national, regional and local, to encourage SMEs to be innovative and to cooperate and interact with knowledge providers (universities, research institutes, innovation centers, etc.).

\section{References:}

Case studies. Innovation Vouchers Website (n.d.). Retrieved October 17, 2021, from: https://www.innovationvouchers.com/case-studies/

Case study 7: Regional innovation vouchers as an effective tool for supporting technology transfer (2015). Effective Technology Transfer in Biotechnology, 90-107. DOI: https://doi.org/10.1142/9781783266814_0007

Chiu, W.-H., Lin, W. C., \& Liang, C.-J. (2021). The role of Green Finance in community renewable energy projects of Main Region and Taiwan. Lex Localis - Journal of Local Self-Government, 19(3), 503-519. DOI: https://doi.org/10.4335/19.3.503-519(2021)

Cornet, M., Vroomen Björn, \& Marc van der Steeg (2006). Do innovation vouchers help smes to cross the bridge towards science? CPB Netherlands Bureau for Economic Policy Analysis.

de Savigny, D., Webster, J., Agyepong, I. A., Mwita, A., Bart-Plange, C., Baffoe-Wilmot, A., Koenker, H., Kramer, K., Brown, N., \& Lengeler, C. (2012). Introducing vouchers for malaria prevention in Ghana and Tanzania: Context and adoption of innovation in Health Systems. Health Policy and Planning, 27(suppl 4), iv32-iv43. DOI: https://doi.org/10.1093/heapol/czs087

Efigence (n.d.). Innovation vouchers for smes (product PARP) - Polish Development Fund Group. Polski Fundusz Rozwoju (Grupa PFR). Retrieved October 17, 2021, from: https://pfr.pl/en/offer/innovation-vouchers-for-smes.html

Guerrero, M., \& Urbano, D. (2019). Effectiveness of technology transfer policies and legislation in fostering entrepreneurial innovations across continents: An overview. The Journal of Technology Transfer, 44(5), 1347-1366. DOI: https://doi.org/10.1007/s10961-019-09736-x

Hlaváček, P. (2017). Use of innovation vouchers for the Regional Innovation Environment Development. Economic Annals-XXI, 166(7-8), 91-95. DOI: https://doi.org/10.21003/ea.v166-18

Innovation vouchers (n.d.). Retrieved October 17, 2021, from: https://www.innovationpolicyplatform.org/ www.innovationpolicyplatform.org/sites/default/files/rdf_imported_documents/InnovationVouchers/index.pdf Innovation vouchers. Enterprise Ireland (EI) (n.d.). Retrieved October 17, 2021, from: https://www.enterprise-ireland.com/en/research-innovation/companies/collaborate-with-companies-researchinstitutes/innovation-voucher.shortcut.html

Innovation vouchers. Innovation Policy Platform (n.d.). Retrieved October 17, 2021, from: https://www.innovationpolicyplatform.org/www.innovationpolicyplatform.org/content/innovation-vouchers/ index.html

Kholiavko, N., Grosu, V., Safonov, Y., Zhavoronok, A., \& Cosmulese, C. G. (2021). Quintuple helix model: investment aspects of higher education impact on sustainability. Management Theory and Studies for Rural Business and Infrastructure Development, 43(1), 111-128. DOI: https://doi.org/10.15544/mts.2021.10 
Langhorn, K. (2014). Encouraging entrepreneurship with innovation vouchers: Recent experience, lessons, and Research Directions. Canadian Public Administration, 57(2), 318-326. DOI: https://doi.org/10.1111/ capa. 12070

Luksic, I., Boskovic, B., Novikova, A., \& Vrbensky, R. (2021). Innovative Financing of the Sustainable Development Goals in the countries of Western Balkans. DOI: https://doi.org/10.21203/rs.3.rs-853207/v1

Matulova, P., Stemberkova, R., Zdralek, P., Maresova, P., \& Kuca, K. (2015). Innovation vouchers as a segment of regional innovation strategy. Procedia Economics and Finance, 26, 842-848. DOI: https://doi.org/10.1016/ s2212-5671(15)00891-6

Nstathom (2021, November 8). Innovation vouchers for small and medium-sized enterprises. Innovation vouchers for small and medium-sized enterprises - Internal Market, Industry, Entrepreneurship And Smes - European Commission. Retrieved October 17, 2021, from: https://ec.europa.eu/growth/tools-databases/regionalinnovation-monitor/support-measure/innovation-vouchers-small-and-medium-sized-enterprises

Outterson, K., \& McDonnell, A. (2016). Funding antibiotic innovation with vouchers: Recommendations on how to strengthen a flawed incentive policy. Health Affairs, 35(5), 784-790. DOI: https://doi.org/10.1377/ hlthaff.2015.1139

Raimi, L., Olowo, R., \& Shokunbi, M. (2021). A comparative discourse of sustainable finance options for agribusiness transformation in Nigeria and Brunei: Implications for entrepreneurship and enterprise development. World Journal of Science, Technology and Sustainable Development, ahead-of-print (ahead-of-print). DOI: https: //doi.org/10.1108/wjstsd-05-2021-0051

Sadiq, M., Nonthapot, S., Mohamad, S., Chee Keong, O., Ehsanullah, S., \& Iqbal, N. (2021). Does green finance matter for sustainable entrepreneurship and environmental corporate social responsibility during COVID-19? China Finance Review International, ahead-of-print (ahead-of-print). DOI: https://doi.org/10.1108/cfri-022021-0038

Sala, A., Landoni, P., \& Verganti, R. (2015). Small and medium enterprises collaborations with Knowledge Intensive Services: An explorative analysis of the impact of innovation vouchers. R\&D Management, 46(S1), 291-302. DOI: https://doi.org/10.1111/radm.12196

Schade, S., \& Grigore, C. (2009) (rep.). Availability and Focus on Innovation Voucher Schemes in European Regions.

Shavina, E., \& Prokofev, V. (2020). Implementation of environmental principles of sustainable development in the mining region. E3S Web of Conferences, 174, 02014. DOI: https://doi.org/10.1051/e3sconf/202017402014

Shein, E. G., Payusov, A. A., \& Kurdyumov, A. V. (2020). Formation of socially oriented projects using the financial and investment mechanism in the field of Environmental Management. E3S Web of Conferences, 222, 06035. DOI: https://doi.org/10.1051/e3sconf/202022206035

Shevchenko, T., Vavrek, R., Danko, Y., Gubanova, O., \& Chovancová, J. (2021). Clarifying a circularity phenomenon in a circular economy under the notion of potential. Problemy Ekorozwoju, 16(1), 79-89. DOI: https://doi.org/10.35784/pe.2021.1.09

Shkarlet, S., Kholiavko, N., \& Dubyna, M. (2019). Information economy: Management of educational, innovation, and research determinants. Marketing and Management of Innovations, (3), $126-141$. DOI: https://doi.org/10.21272/mmi.2019.3-10

SME Innovation Voucher Scheme. SME Innovation Voucher Scheme | University of Surrey (n.d.). Retrieved October 17, 2021, from: https://www.surrey.ac.uk/innovation/funding/sme-innovation-voucher-scheme

Spiesberger, M., \& Schönbeck, J. (2019). Innovation vouchers for Energy and Innovation Systems' Transition. Foresight and STI Governance, 13(1), 70-76. DOI: https://doi.org/10.17323/2500-2597.2019.1.70.76

STIP COMPASS: International Database on Science Technology and Innovation Policies (n.d.). Retrieved October 17, 2021, from: https://stip.oecd.org/

Voucher schemes in member States - European Commission (n.d.). Retrieved October 17, 2021, from: https://ec.europa.eu/information_society/newsroom/image/document/2019-32/member_states_use_of_ voucher_schemes_0D31F683-AA92-B7FF-684433BCBD8A4F3A_61225.pdf

Voucher schemes: Zooming in on Innovation Vouchers. Interreg Europe. (n.d.). Retrieved October 17, 2021, from: https://www.interregeurope.eu/policylearning/news/10861/voucher-schemes-zooming-in-on-innovationvouchers/

Yakymchuk, A., Popadynets, N., Valyukh, A., Skrypko, T., \& Levkov, K. (2021). Rural "green" tourism as a catalyst for local economic development amidst decentralization of power. Agricultural and Resource Economics: International Scientific E-Journal, 232-259. DOI: https://doi.org/10.51599/are.2021.07.01.12

Zhao, R., \& Radziwon, A. (2021). The impact of innovation vouchers on Green Innovation Efficiency. Academy of Management Proceedings, 1, 14580. DOI: https://doi.org/10.5465/ambpp.2021.156 
Appendix A

Successful examples of the implementation of innovative vouchers

\begin{tabular}{|c|c|c|c|c|c|}
\hline $\begin{array}{c}\text { № of } \\
\text { project }\end{array}$ & Project name & $\begin{array}{l}\text { Sector / } \\
\text { Company }\end{array}$ & Challenge & Innovation voucher solution & Impact \\
\hline 1 & $\begin{array}{l}\text { Reduction } \\
\text { of Weather } \\
\text { Risk System } \\
\text { (RoWeRS } \\
\text { method) }\end{array}$ & $\begin{array}{l}\text { Construction } \\
\text { (AMG } \\
\text { company) }\end{array}$ & $\begin{array}{l}\text { The construction process } \\
\text { is virtually independent of } \\
\text { weather conditions, especially } \\
\text { wet conditions. The RoWeRS } \\
\text { method developed can simplify } \\
\text { the construction process by } \\
\text { using standardized parts, } \\
\text { making construction cheaper } \\
\text { and easier. }\end{array}$ & $\begin{array}{l}\text { Construction company AMG } \\
\text { applied for an Innovation } \\
\text { Voucher grant, received it, and } \\
\text { negotiated with architectural } \\
\text { firm GH Design to develop } \\
\text { architectural details for } \\
\text { applying the RoWeRS method } \\
\text { to construction processes. }\end{array}$ & $\begin{array}{l}\text { The RoWeRS method and } \\
\text { its standard have become } \\
\text { a key component in the } \\
\text { construction industry. } \\
\text { AMG exceeded all } \\
\text { KPIs, namely: turnover, } \\
\text { productivity, personnel } \\
\text { qualification. }\end{array}$ \\
\hline 2 & $\begin{array}{l}\text { High-efficiency } \\
\text { filters }\end{array}$ & $\begin{array}{l}\text { Manufacturing } \\
\text { (Airguard } \\
\text { Filters) }\end{array}$ & $\begin{array}{l}\text { Development of a new product } \\
\text { aimed at the clean circulation } \\
\text { of filtered air for any device. } \\
\text { Lack of funding for equipment } \\
\text { and production, as well as } \\
\text { the company's inability to } \\
\text { implement the product, was } \\
\text { the reason for applying for the } \\
\text { Innovation Voucher program. }\end{array}$ & $\begin{array}{l}\text { The Innovation Voucher } \\
\text { collaboration with Bridge } \\
\text { PR and Media enabled an } \\
\text { extensive PR strategy (press } \\
\text { releases, LinkedIn presence, } \\
\text { technical presentations, etc.) } \\
\text { that resulted in Airguard } \\
\text { Filters becoming a member of } \\
\text { the Railway Alliance and its } \\
\text { products proving very useful } \\
\text { to the Rail Sector. }\end{array}$ & $\begin{array}{l}\text { The marketing and } \\
\text { promotion strategy } \\
\text { developed as part of the } \\
\text { Innovation Voucher } \\
\text { program was the basis } \\
\text { for launching a portfolio } \\
\text { of new products. The } \\
\text { company's KPIs such as } \\
\text { sales and profitability were } \\
\text { increased, and new jobs } \\
\text { were created. }\end{array}$ \\
\hline 3 & $\begin{array}{l}\text { "Business } \\
\text { Dashboard" } \\
\text { online business } \\
\text { audit tracking }\end{array}$ & $\begin{array}{l}\text { Business Services } \\
\text { (Business Delta) }\end{array}$ & $\begin{array}{l}\text { As a result of the Due Diligence, } \\
\text { the company produced a } \\
\text { detailed action plan specifying } \\
\text { the necessary KPIs in various } \\
\text { areas such as sales, marketing, } \\
\text { HR, and finance, as well as } \\
\text { recommendations for increasing } \\
\text { the value of the business. } \\
\text { However, monitoring the results } \\
\text { over time required additional } \\
\text { expertise of consultants. The } \\
\text { developed online audit system } \\
\text { made it possible to track the } \\
\text { results of consultants' work and } \\
\text { offer professional advice and } \\
\text { support at every stage of the } \\
\text { business online. }\end{array}$ & $\begin{array}{l}\text { The Innovation Voucher } \\
\text { program has paid for } \\
\text { the implementation of } \\
\text { developed IT specifications } \\
\text { and the application of } \\
\text { "Proof of Concept" as part } \\
\text { of the Innovation Voucher } \\
\text { Authorized Company } \\
\text { collaboration. }\end{array}$ & $\begin{array}{l}\text { The company's turnover } \\
\text { has grown tremendously, } \\
\text { and due to the constant } \\
\text { demand for the system } \\
\text { used, additional IT } \\
\text { specialists as well as } \\
\text { auditors were required. } \\
\text { The new "Business } \\
\text { Dashboard" provides the } \\
\text { ability to monitor all KPIs, } \\
\text { this product offered a new } \\
\text { demanding service for the } \\
\text { market. }\end{array}$ \\
\hline 4 & $\begin{array}{l}\text { Application for } \\
\text { delivery of cars } \\
\text { by individual } \\
\text { drivers }\end{array}$ & $\begin{array}{l}\text { Logistics (DMN } \\
\text { Logistics) }\end{array}$ & $\begin{array}{l}\text { The payroll system was based } \\
\text { on hours worked, and managing } \\
\text { and controlling the workflow } \\
\text { and schedule of employees was } \\
\text { too complicated (faxes, mail). } \\
\text { A possible solution could be an } \\
\text { application designed to keep } \\
\text { track of employees and update } \\
\text { their current status instantly. }\end{array}$ & $\begin{array}{l}\text { The Innovation Voucher grant } \\
\text { was to work with the Business } \\
\text { Growth Hub to develop an } \\
\text { application that would record } \\
\text { and store all data related to the } \\
\text { workflow of individual drivers, } \\
\text { such as hours worked, their } \\
\text { location, jobs completed, etc. }\end{array}$ & $\begin{array}{l}\text { Increased productivity, } \\
\text { fast account management, } \\
\text { job creation, excess } \\
\text { turnover and profits. }\end{array}$ \\
\hline 5 & $\begin{array}{l}\text { Cooperation } \\
\text { between SMEs } \\
\text { and University } \\
\text { of Surrey }\end{array}$ & $\begin{array}{l}\text { Know-how, } \\
\text { academic } \\
\text { expertise }\end{array}$ & $\begin{array}{l}\text { The lack of specialists } \\
\text { involved in SMEs leads to a } \\
\text { limited number of innovation } \\
\text { processes, a lack of proven } \\
\text { expertise in new technologies } \\
\text { and the development of new } \\
\text { projects, as well as their testing } \\
\text { and implementation. }\end{array}$ & $\begin{array}{l}\text { The Innovation Voucher } \\
\text { Scheme aims to cover the } \\
\text { services of the University } \\
\text { of Surrey in relation to } \\
\text { innovative projects at different } \\
\text { stages from development to } \\
\text { implementation. The funding } \\
\text { amount for an innovation } \\
\text { voucher ranges from } 5,000 \text { to } \\
10,000 \text { pounds. }\end{array}$ & $\begin{array}{l}\text { Strengthening innovation } \\
\text { projects in the SME } \\
\text { sector, as well as recovery } \\
\text { from Covid-19, } \\
\text { introduction of new } \\
\text { processes, academic } \\
\text { expertise in new areas } \\
\text { related to Business, } \\
\text { Innovation and Social } \\
\text { Sciences. }\end{array}$ \\
\hline
\end{tabular}


(End of Appendix A)

\begin{tabular}{|c|c|c|c|c|c|}
\hline $\begin{array}{c}\text { № of } \\
\text { project }\end{array}$ & Project name & $\begin{array}{l}\text { Sector / } \\
\text { Company }\end{array}$ & Challenge & Innovation voucher solution & Impact \\
\hline 6 & $\begin{array}{l}\text { Innovation } \\
\text { vouchers for } \\
\text { SMEs that do } \\
\text { not have their } \\
\text { own resources } \\
\text { for R\&D }\end{array}$ & R\&D, innovation & $\begin{array}{l}\text { SMEs lack the ability to } \\
\text { develop and implement } \\
\text { product innovations, service } \\
\text { innovations, and process } \\
\text { innovations. } \\
\text { Therefore, SMEs can benefit } \\
\text { from the experience and } \\
\text { expertise of research institutes. }\end{array}$ & $\begin{array}{l}\text { Innovation voucher A: up } \\
\text { to 2,500 euros (max. } 80 \% \text { of } \\
\text { costs) for activities leading } \\
\text { up to the development of the } \\
\text { innovative product. } \\
\text { Innovation voucher B: up to } \\
5,000 \text { euros (max. } 50 \% \text { of the } \\
\text { costs) for the implementation } \\
\text { of R\&D processes. } \\
\text { Hightech Start-up Innovation } \\
\text { Voucher: up to } 20,000 \text { euros } \\
\text { (max. 50\% of costs) for R\&D } \\
\text { implementation in specific } \\
\text { areas such as ICT, green IT, life } \\
\text { sciences, etc. } \\
\text { Hightech Digital Innovation } \\
\text { Voucher: } € 20,000 \text { (max. } 50 \% \\
\text { of costs) to implement R\&D in } \\
\text { areas related to digitalization } \\
\text { and Industry } 4.0 . \\
\text { Hightech Mobility Innovation } \\
\text { Voucher: } 20,000 \text { euros (max. } \\
50 \% \text { of costs) for R\&D } \\
\text { implementation in areas } \\
\text { related to future mobility. }\end{array}$ & $\begin{array}{l}\text { Development and } \\
\text { implementation of } \\
\text { business R\&D and } \\
\text { innovation SMEs. }\end{array}$ \\
\hline
\end{tabular}

Source: formed by authors on the basis of (Guerrero, Urbano, 2019; Innovation vouchers. Enterprise Ireland (EI); Innovation vouchers. Innovation Policy Platform; Kholiavko, Grosu, Safonov, Zhavoronok, Cosmulese, 2021; Shkarlet, Kholiavko, Dubyna, 2019; Spiesberger, Schönbeck, 2019; STIP COMPASS) 